\title{
Cabochonicus, a new genus for species of gemmate megaspores previously referred to Verrutriletes
}

\author{
${ }^{1}$ D. J. BATTEN \& ${ }^{2}$ D. J. P. FERGUSON \\ ${ }^{1}$ Department of Geology and Mineralogy, Marischal College, University of Aberdeen, Aberdeen AB9 1AS \\ ${ }^{2}$ Nuffield Department of Pathology, John Radcliffe Hospital, University of Oxford, Headington, Oxford OX3 9DU
}

\begin{abstract}
Several species of Mesozoic megaspores that are sculptured with globular, often gemmate elements are sufficiently distinct from most verrucate forms to warrant their inclusion in a genus other than Verrutriletes. Cabochonicus is erected to accommodate them with $C$. (al. Verrutriletes) carbunculus as the type species. The form of the gemmae, which have a glossy appearance, has been the subject of past debate with one interpretation being that they are the manifestation of fungal attack rather than sculpture. Evidence from ultrastructural studies suggests, however, that they are exinal excrescences. The spores are assumed to be the products of heterosporous lycopods and the structure of the wall layers may indicate selaginellalean affinities. The plants are more likely to have been terrestrial than aquatic or semi-aquatic.
\end{abstract}

\section{INTRODUCTION}

In an attempt to determine whether the spherular surface elements of the Mesozoic megaspore Verrutriletes carbunculus and similar forms are morphological features or the product of some external phenomenon, several specimens attributable to the genus were thin sectioned and examined under a transmission electron microscope (TEM). At the same time, it was hoped that the structure of the rest of the protective sporopollenin wall layers could be ascertained, thus enabling comparisons to be made with the composition of exines of modern megaspores which, in turn, could possibly shed some light on the botanical affinity of the extinct plants that produced them.

Two main conclusions were reached concerning the first of these aims: 1) the gemmae are surface excrescences that can be accepted for descriptive purposes as sculptural elements and 2) neither Verrutriletes van der Hammen ex Potonié nor Trileites Erdtman ex Potonié accommodate the spores satisfactorily. The arguments in favour of setting up the new genus that is necessary are presented here using nomenclature that has been appropriate to date. This leads to a short systematic section in which Cabochonicus is formally erected and species attributable to it are listed. The paper concludes with a brief consideration of the botanical affinity of the genus and of the palaeoecological implications of its distribution.

\section{BACKGROUND TO PROBLEM}

The generic name Verrutriletes was erected by van der Hammen (1954) but it was a nomen nudum until 1956 when a type species was designated by Potonié. He selected one of the megaspores that Dijkstra (1949) had described from the Upper Cretaceous of the Netherlands, namely Triletes compositipunctatus. This is a relatively small spore (usually significantly less than $500 \mu \mathrm{m}$ in diameter) with conspicuous triradiate ridges and a surface sculpture that consists of numerous granula, verrucae and rugulae. These were originally described as being hemispherical elements $5-20 \mu \mathrm{m}$ high, $5-30 \mu \mathrm{m}$ broad, sometimes smaller $(5 \mu \mathrm{m})$ on the contact areas and often united into star-shaped groups or rows $(70 \mu \mathrm{m}$ long) on the distal surface (Dijkstra, 1949; Potonié, 1956).

Potonié's diagnosis of the genus allows for the surface elements to range from hemispherical verrucae to low coni of variable size, and for the proximal face to lack sculpture. Binda \& Srivastava (1968) emended it to include specific reference to the trilete rays which they stated may or may not reach the equator, Potonié not having allowed for the former condition.

Seven species were originally included in the genus. There are now more than 30, approximately half of which have been described from Cretaceous rocks; all are Mesozoic. The taxonomic status of a few, and in particular of Verrutriletes carbunculus (Dijkstra, 1949) Potonié, 1956 has, however, become increasingly confused during the past few years because of uncertainty about the true nature of the sculptural elements which are not strictly verrucae. Dijkstra (1949). described them as hemispherical, red, translucent objects. Potonié (1956) noted that they are irregularly scattered like glossy, resin droplets; this led him to place the species only provisionally in Verrutriletes. Knobloch (1984a, pp. $168-169 ; 1984$ b, p. 156) has referred to them as "glass beads dyed red-brown" and 'pearl-like orna- 
ments", and for one specimen he compared them to small "bits of tar".

Marcinkiewicz (1979) decided that the spherules are not sculpture but fungal elements which are attached to the surface of the essentially smooth-walled Trileites murrayi (Harris, 1961) Marcinkiewicz, 1971. They were placed in a new genus and species, Reymanella globosa. Other megaspores whose exines she interpreted to be similarly modified by fungal organisms are Triletes imitatus Dijkstra, 1961 (transferred to Verrutriletes by Waksmundzka, 1982), Verrutriletes pseudosquamosus Marcinkiewicz, 1962 and Verrutriletes sp. in Marcinkiewicz (1962). Verrutriletes guttatus Marcinkiewicz, 1971 can also be included in this list.

Besides the obvious bead-like appearance of the elements, there are a few additional points in favour of Marcinkiewicz's argument. The spherules are often basally constricted and appear to be held onto the spore by means of short appendages. Banerji et al. (1984) noted that they dissolve in acid without leaving a trace on the surface of the spores they examined (recovered from probable Lower Cretaceous rocks in Kachchh, India); regardless of the type of acid used (not stated in their paper), this suggests a composition different from that of the protective wall. The common sedimentary association of $V$. carbunculus with unornamented but otherwise similar Trileites murrayi could be taken to indicate that they are the same taxon, the latter not having been affected by $R$. globosa.

Several arguments can, however, also be made against such an interpretation. The spherules look far more like "resinous" droplets or excrescences than fungal bodies. They are commonly concentrated in a broad band centred on the equator (e.g. Heuber, 1982, pl. 2, figs. 4, 5; Kampmann, 1983, pl. 7, figs. 1a-d). In some specimens, the entire distal surface is also covered (e.g. Knobloch, 1984b, pl. 1, fig. 2). This suggests a morphological character and not a fungal infestation, which would be expected to produce a random pattern. Apparently haphazard distributions do occur on some specimens, and they may be present in patches on the proximal face between and/or on the triradiate ridges (e.g. Marcinkiewicz, 1980, pl. 3, figs. 2, 3). On the other hand, Hueber (1982, pl. 2, fig. 1), Kampmann (1983, pl. 7, fig. 1c) and others have illustrated specimens whose original tetrad configuration is clearly delineated by smooth contact areas bordered by closely-spaced spherules.

\section{MATERIAL AND METHODS}

Verrutriletes (Cabochonicus in systematic section and on Pls. 1-4) carbunculus is usually recovered only as isolated specimens in preparations for large plant microfossils. Those reported on herein come from Lower Cretaceous (Wealden) samples, and from Dijkstra's type assemblage which is of Senonian age. The ornamentation of both sets of specimens varies from consisting of a few widely scattered, relatively large globular elements to smaller, more densely arranged and less well rounded bodies whose bases frequently merge together.

By comparison with the majority of Cretaceous megaspores, $V$. carbunculus is large (sometimes more than $1 \mathrm{~mm}$ in diameter) and usually brittle, whole specimens being uncommon. The Lower Cretaceous

\section{Explanation of Plate 1}

All scanning election micrographs of megaspores from the English Wealden (Lower Cretaceous). Figs. 1-4. Cabochonicus carbunculus from the Ashdown Beds Formation (sample DJB 39):

Fig. 1. Enlargement of right-hand side of specimen illustrated in fig. 3 showing mode of attachment of exinal excrescences $(\times 200)$.

Fig. 2. Detail of a single spherule and of perforated exoexine on left-hand side of specimen in fig. $3(\times 1500)$.

Fig. 3. Deflated specimen showing most of proximal and part of distal surface $(\times 50)$.

Fig. 4. Detail of pitted surface of fig. 3 close to the triradiate ridge $(\times 2000)$.

Fig. 5. Obliquely compressed Trileites murrayi from the Wadhurst Clay Formation (sample DJB/HB/54H) $(\times 50)$.

Fig. 6. Surface detail of above $(\times 10,000)$.

Fig. 7. Damaged Cabochonicus sp. from the Ashdown Beds Formation (sample DJB218) which is sculptured with very small (granule-sized) and densely distributed spherules; part of intexine also visible $(\times 40)$.

Fig. 8. Damaged Cabochonicus sp. partly split open along trilete suture showing densely distributed sculptural elements and intexine peeling away from exoexine; Ashdown Beds Formation (sample DJB218) $(\times 40)$.

Fig. 9. Sculptural detail of above showing protruberances with merging bases and some surface damage $(\times 300)$. 

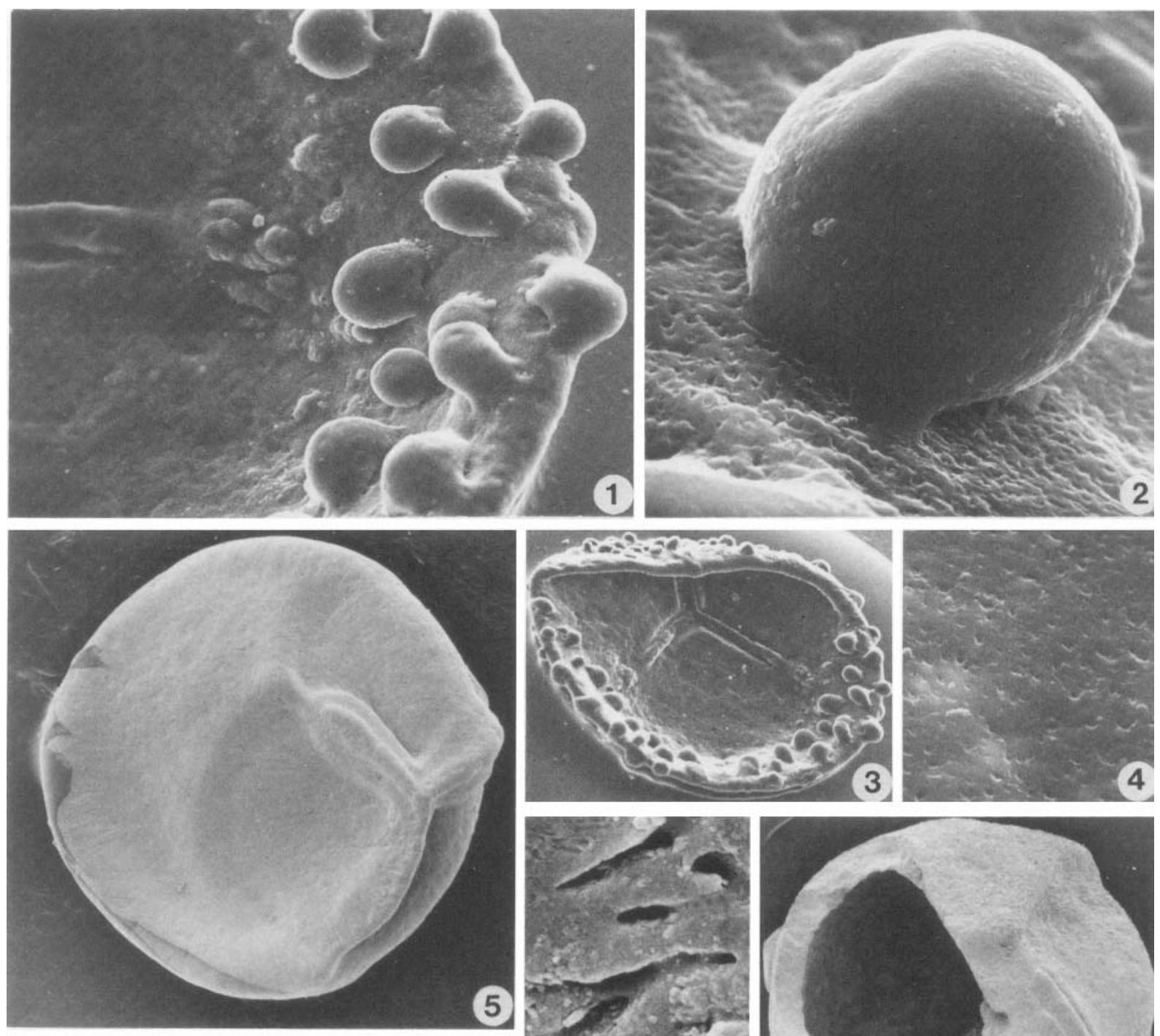

5
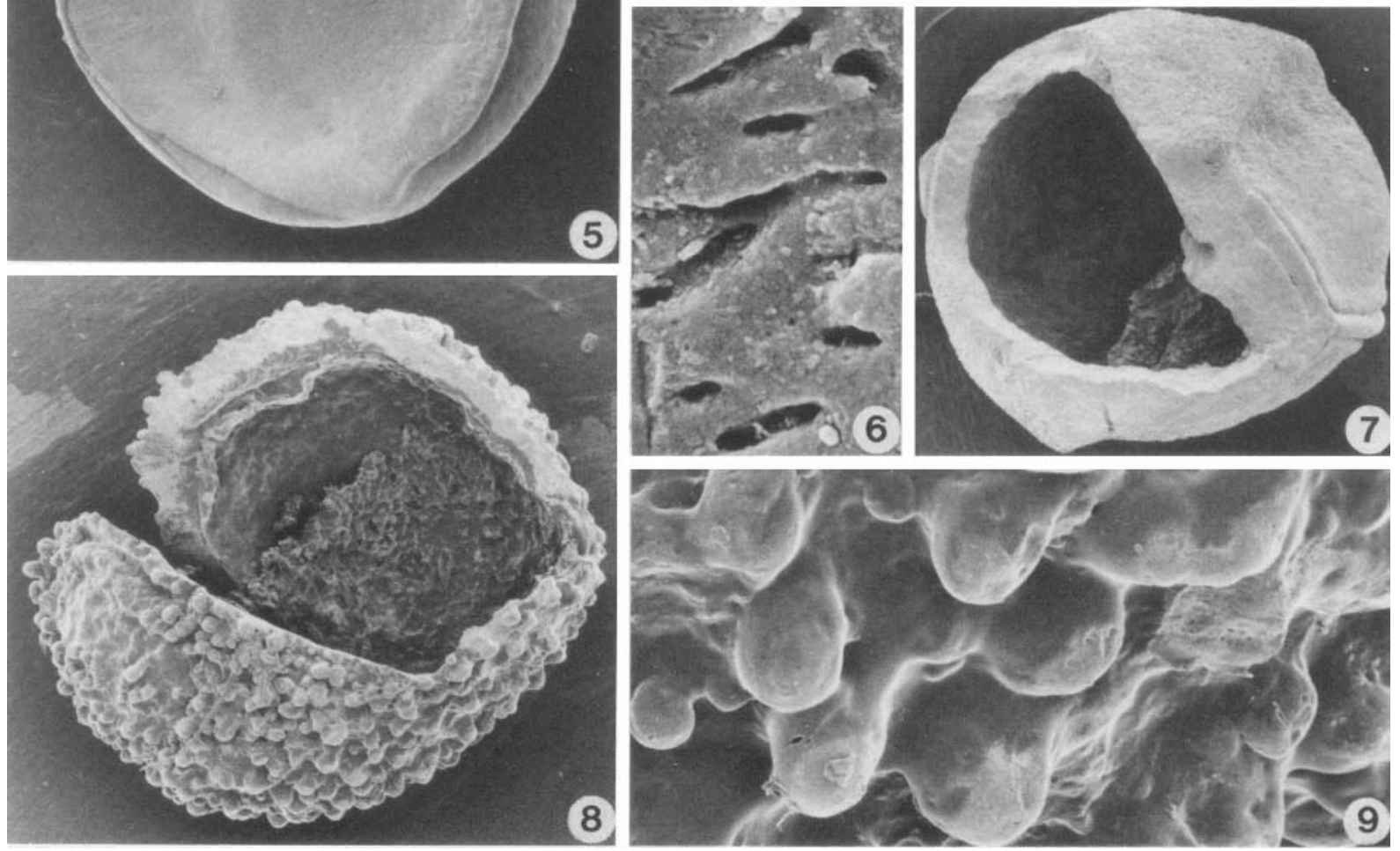
collection includes some complete spores but with the exception of one comparatively small form, the type material is entirely fragmentary, consisting of fewer than ten additional bits.

In view of both the scarcity of undamaged specimens and the large size of the spores, only small fragments were thin sectioned. The procedure adopted for this was as follows: each piece was 1) immersed in a saturated solution of Uranyl acetate for 30 minutes, 2) washed three or four times in distilled water, 3) soaked in a 1:1 mixture of EMix epoxy resin and Analar Acetone, and 4) embedded in resin formulated to set to a medium hardness. The resin blocks were trimmed and the thin sections cut using glass knives and Reichert OmU3 and OmU4 ultramicrotomes respectively. Selected sections were placed on Formvar-coated slot grids, examined under a Philips 301 TEM and photographed. The scanning electron micrographs were obtained using microscopes at the University of East Anglia and the British Museum (Natural History). The specimens were coated with gold prior to examination.

\section{SURFACE MORPHOLOGY}

A typical representative of Verrutriletes carbunculus in polar view shows well rounded to globular bodies scattered over the surface of the spore in equatorial and subequatorial regions, the triradiate ridge and areas between the rays being devoid of them ( $\mathrm{Pl}$. 1, fig. 3; referred to Cabochonicus). These elements mostly appear to be held in place by "straps" or "root-like" structures extending from their bases onto the surface of the exine (Pl. 1, figs. 1, 2; Pl. 2, figs. 1,2). Although at low magnifications the latter looks smooth, at high power it is seen to be uneven and irregularly perforated (Pl. 1, figs. 2, 4). Without the spherules the species is clearly similar to some smooth walled species, particularly Trileites murrayi (Harris, 1961) Marcinkiewicz, 1971 (Pl. 1, figs. 5, 6).

Marcinkiewicz (1979, pl. 3, fig. 3) figured an almost identical specimen which she identified as $T$. murrayi with spherules of Reymanella globosa Marcinkiewicz on its surface. Other closely comparable forms are illustrated in Pelzer \& Reigel (1982, pl. 1, figs. 5, 6), Huckriede (1982, pl. 8, figs. 1a-c, 2), and Collinson et al. (1985, fig. 3b). The last of these authors chose not to follow Dijkstra (1951) and positively referred their Lower Cretaceous specimens to Verrutriletes carbunculus. Most of the other illustrations of the species in the literature are also very similar although some differences in density, size, shape and distribution of the spherules is evident. Several show a tendency for the ornament to be concentrated, or to comprise larger elements, in equatorial and subequatorial regions (e.g. in Hueber, 1982; Kampmann, 1983; Knobloch, 1984a, b; Banerji et al., 1984; Batten et al., 1984; Batten \& Li, in press).

Verrutriletes imitatus (Dijkstra, 1961) Waksmundzka, 1982 is a similar spore. It differs in supposedly having a less well rounded outline in polar view and in being more evenly covered with spherules. In practice, its distinction from $V$. carbunculus is not always clear. $V$. pseudosquamosus Marcinkiewicz, 1962 is stated to be characterised by the occurrence on its outer surface of "somewhat transparent" discs (Marcinkiewicz, 1962, p. 491; 1979). The globular bodies on $V$. guttatus Marcinkiewicz, 1971 are very variable in size, some being well over five times as large as others. Triletes gamerroi Baldoni \& Taylor, 1985 is similar to Verrutriletes sp. in Marcinkiewicz (1962) in bearing only isolated spherules; both of these are like sparsely ornamented $V$. carbunculus.

\section{Explanation of Plate 2}

Figs. 1 and 2, transmitted light photographs. Figs. 3-8, all ultrathin sections of fragments of Cabochonicus carbunculus from Dijkstra's (1949) type collection.

Fig. 1. Surface of Cabochonicus sp. from the Ashdown Beds Formation (sample DJB 218) after being rendered translucent by oxidation in fuming. $\mathrm{HNO}_{3}(\times 500)$.

Fig. 2. Surface of fragment of $C$. carbunculus from Dijkstra's (1949) type collection after oxidation as above $(\times 500)$.

Fig. 3. Elongate globule, specimen $1(\times 5000)$.

Fig. 4. Conical protruberance, specimen $1(\times 5000)$.

Fig. 5. Flattened globule, specimen $1(\times 2500)$.

Fig. 6. Tangential section through exoexine, specimen $3(\times 5000)$.

Fig. 7. Perpendicular section through exoexine showing that the fibrous sporopollenin network is of constant form except close to the inner surface where it becomes more granular with rathér less interstitial air-space; intexine missing, specimen $1(\times 2500)$.

Fig. 8. Thin intexine closely adhering to inner surface of exoexine, specimen $3(\times 2500)$. 

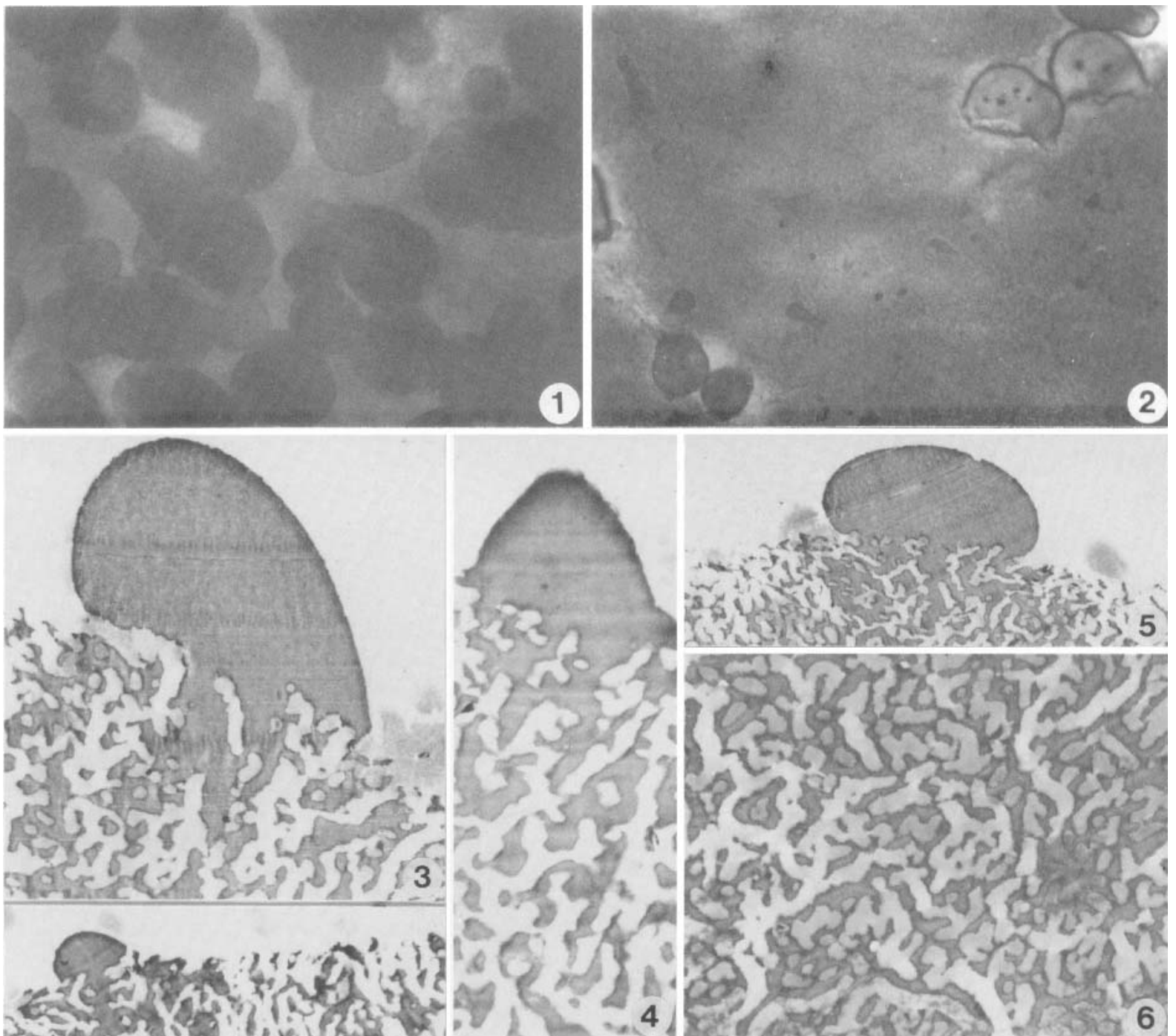
tow ox से fis in Itis? If 7 2.

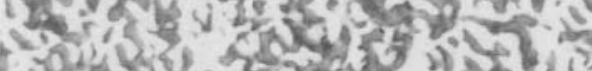
Tox

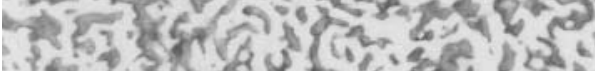

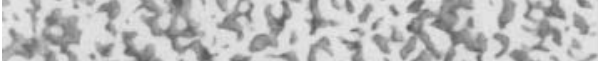

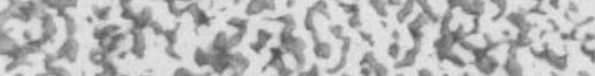

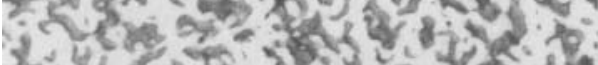

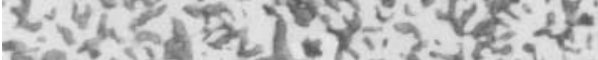
Vit

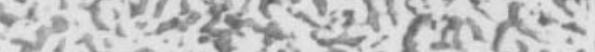

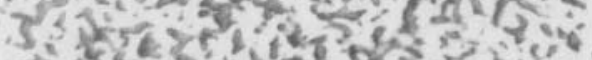

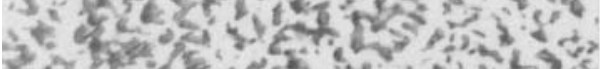
2.1.

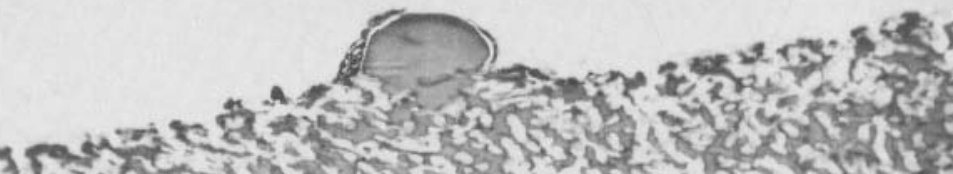

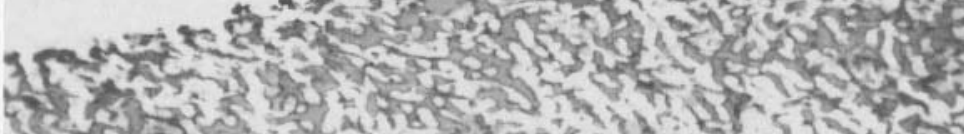

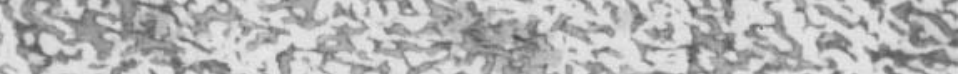

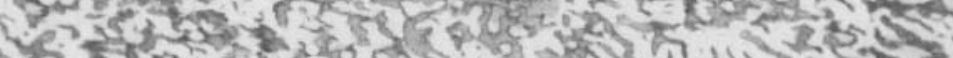

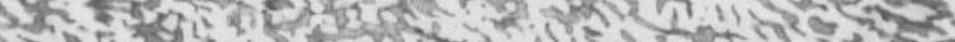

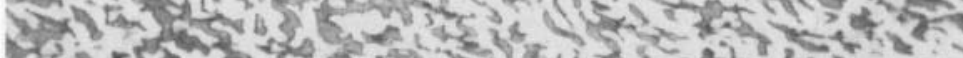

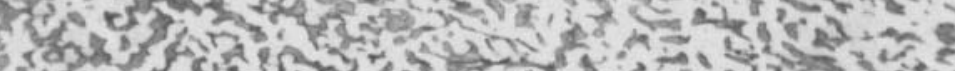

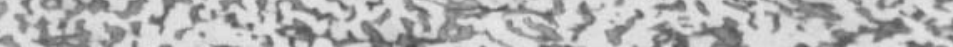

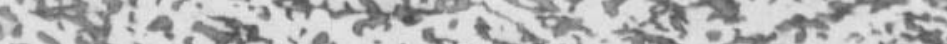

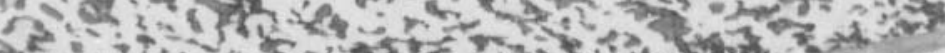

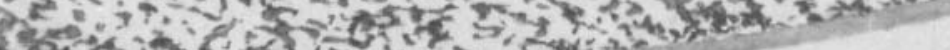
(1) 
The other two specimens illustrated here by scanning electron micrographs (Pl. 1, figs. 7-9) are not readily referable to any of these species. They are more densely ornamented, and the elements are smaller, less globular and frequently merge together at their bases. One of them (Pl. 1, figs. 8, 9) is also sculptured on the contact areas and along the triradiate ridge.

\section{ULTRASTRUCTURE}

A number of terms have been applied to the layers that make up megaspore walls. Several are synonyms, their use depending on author preference but one, perine, has been the subject of controversy. Kempf $(1970,1973)$ argued vigorously that this word should be employed for the thick spongy outer wall, with exine being reserved for the much thinner inner stratum. Although such an interpretation is accepted by some (e.g. Bergad, 1978), many authors regard both layers as exine (e.g. Pettitt, 1966; Tryon \& Lugardon, 1978). They are labelled exoexine and intexine herein.

Transmission electron micrographs of thin sections of the two walls in Verrutriletes carbunculus indicate that the bulk of the exoexine consists of ramifying sporopollenin threads of varying thickness which are orientated approximately normal to the outer surface of the spore, whereas the intexine is a thin, lamellated layer. The exoexinal threads are of constant form except adjacent to the inner surface of the outer wall where they become smaller and/or more densely distributed (e.g. PI. 2, figs. 7,8 ) and in the vicinity of the sculptural elements where they may merge to form more robust units (e.g. Pl. 2, fig. 5). By contrast, the exoexine of a specimen of Trileites murrayi recovered from the Middle Jurassic of Bornholm by Kempf (1971, and referred to therein as Istisporites murrayi (Harris) Kempf, 1971) is made up of three zones of differing character. The inner wall is, however, comparably thin and of similar composition to that in $V$. carbunculus.

The exoexine of specimens 1 and 3 (P1. 2, figs. 3-8; Pl. 3, figs. 1-3) from Dijkstra's collection comprises a particularly open structure with the ratio between threads and intervening air-space being approximately 1:1. On the other hand, the rodlets in specimens 2 (PI. 3 , figs. 4-7) and 4 (Pl. 4, figs. 1-6) are more densely distributed; indeed in the former they are mainly tightly packed. It is possible that the open meshwork reflects some expansion of the wall following maceration in Schulze solution and immersion in Potassium hydroxide. Dijkstra (1949, p. 21) noted that at first he prepared his samples in this way, but later found soaking in water was all that was required for the release of spores from the inorganic matrix. Specimen 2 may not, therefore, have been treated with these chemicals and specimen 4 certainly was not.

The intexine of the thin sectioned spores proved to be less than 1/20th the thickness of the exoexine. It is composed of sporopollenin membranes of up to $0.1 \mu \mathrm{m}$ thick arranged parallel to the surface forming a dense lamellar structure (Pl. 3, fig. 2). The junction with the exoexine is clearly delineated within a narrow zone (maximum width c. $0.4 \mu \mathrm{m}$ ) where the outermost laminae are seen to be discontinuous and partly interspersed with exoexinal threads. Thus, where the two layers are separated, a little of the outer wall commonly remains attached to the inner (Pl. 3, fig. 3).

\section{DISCUSSION}

The observations above on the surface morphology of Verrutriletes carbunculus spores agree with those that have been made by Marcinkiewicz $(1979,1980)$, Knobloch (1984a) and Waksmundzka (1985). The last of these authors also demonstrated that the exoexine consists of irregularly massed sporopollenin threads that pass upwards into dense "verrucae". Her thin

\section{Explanation of Plate 3}

All ultrathin sections of fragments of Cabochonicus carbunculus from Dijkstra's (1949) type collection.

Fig. 1. Intexine partly detached from exoexine, specimen $3(\times 5000)$.

Fig. 2. Detail of junction between exoexine and laminated intexine, specimen $3(\times 15000)$.

Fig. 3. Laminated intexine partly pulled away from exoexine but with a little of the latter still attached, specimen 3 $(\times 5000)$.

Fig. 4. Exoexine composed of interwoven threads similar to those in all preceding figures, but tightly packed with little intervening air-space. Sculpture mostly small spherules but with some more robust elements of varying shape (see figs. 6,7$)$ including conical, specimen $2(\times 2500)$.

Fig. 5. Detail of surface of exoexine with spherules, specimen 2 ( 7500$)$.

Fig. 6. Irregular excrescence, specimen $2(\times 5000)$.

Fig. 7. Surface elements of very variable size, specimen $2(\times 5000)$. 


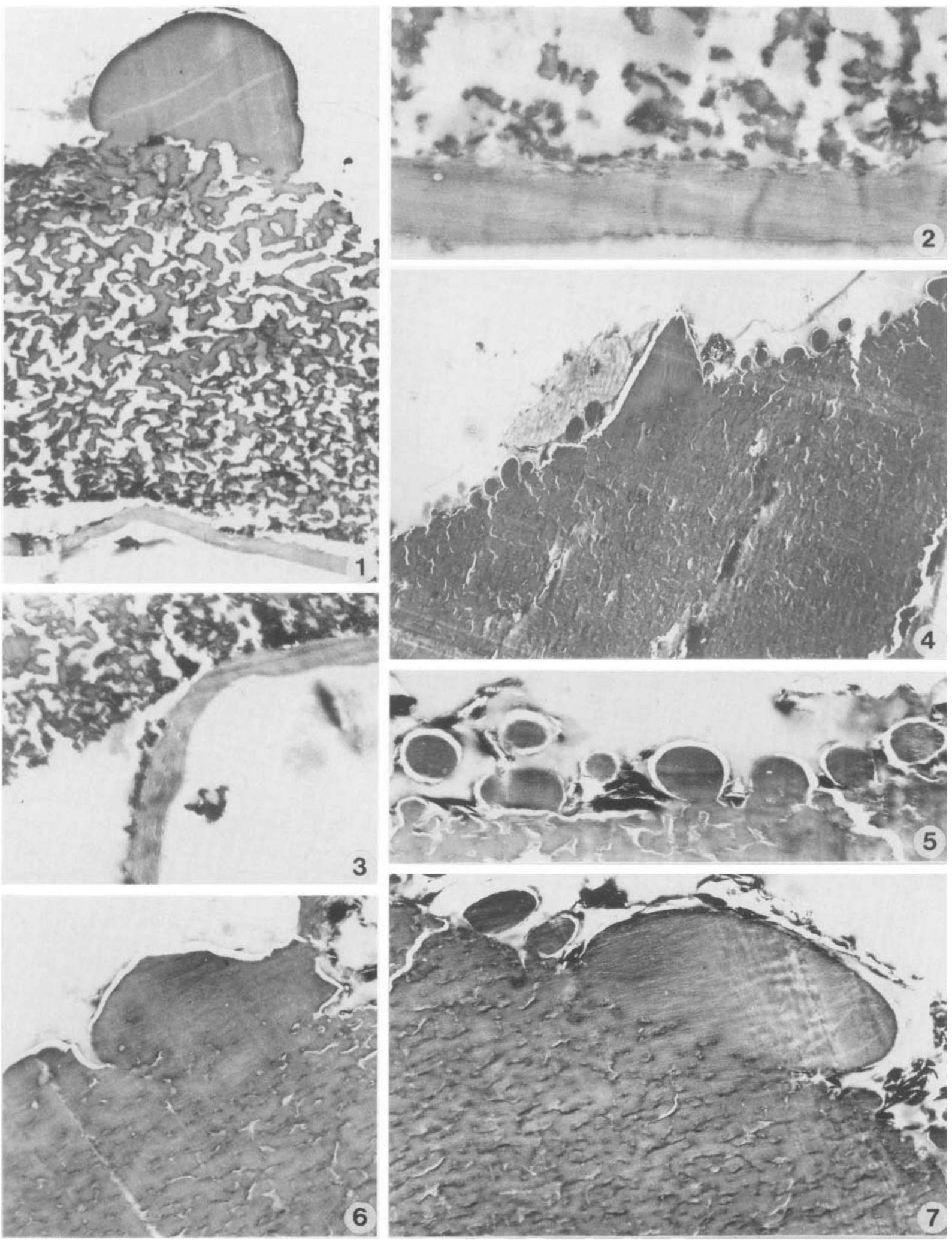


section illustrations (Waksmundzka, 1985, pl. 14, figs. 1-5) tend to emphasise the degree of separation of the surface elements as do several of those herein (e.g. Pl. 2, fig. 3; Pl. 4, fig. 5) but there can be much broader areas of contact with the outer surface (e.g. Pl. 2, figs. 4, 8; Pl. 4, figs. 3, 4, 6). Knobloch (1984a) pointed out that a secretion of a viscous fluid would necessarily produce basal attachment processes. In some instances, the spherules themselves bear excrescences (e.g. Hueber, 1982, pl. 1, fig. 3). Hueber (ibid.) noted that they appear to have been exuded from within the spore as a resinous substance which retained its glossy surface and viscous appearance after solidifying. The internal foam-like composition of the spherules on his Lower Potomac (Virginia) specimens contrasts, however, with the largely solid form of both the Polish (Waksmundzka, 1985) and west European material. Similar structuring may be apparent within degraded elements if the spongy exoexine is raised up under them in the manner shown on P1. 4, figs. 3, 4. It could also be a corrosion effect.

Although looking as if they have been exuded from within the spore, the thin sections do not indicate any exoexinal modification that supports such an interpretation. Despite their shiny appearance in reflected light, there is no evidence of a compositional difference but rather merely a gradation from a spongy texture to solid masses. Their mode of formation thus remains problematical. Whatever their origin, however, the fact that they are not true verrucae renders unsatisfactory the inclusion in Verrutriletes of spores on which they occur. Since thin sectioning has proved that the elements should be treated as a form of sculpture and not the product of fungal attack, reference to Trileites is also inappropriate. The only logical course of action to follow is, therefore, to erect a new genus to accommodate them.

\section{SYSTEMATIC PALAEONTOLOGY}

Cabochonicus gen. nov.

Type species: Cabochonicus carbunculus (Dijkstra, 1949) comb. nov.

Basionym: Triletes carbunculus Dijkstra, 1949, p. 22, pl. 1, fig. 12 .
Diagnosis: A triradiate megaspore of simple form that bears glossy, resinous-looking gemmae and other sculptural elements surmounting an otherwise essentially smooth exoexine. These surface features tend to be concentrated in equatorial and subequatorial regions and/or on the distal surface but they may also occur on the proximal face between and on the rays of the triradiate ridge. They can be widely scattered or densely packed with bases merging together, and may be as small as granules or comprise large (verrucasized) spherules and protruberances.

Description of holotype: Dijkstra did not designate a holotype for Triletes carbunculus but the single specimen he figured (Dijkstra, 1949, pl. 2, fig. 12) can be accepted as such. It is preserved, albeit now in a fragmented state, in a slide labelled "Holotype" along with a much smaller but complete specimen and a few other pieces. The size and shape of the fragments indicate that it was originally subspherical. Comparison with his figure suggests that it was $c .940 \mu \mathrm{m}$ in diameter including the sculpture (c. $900 \mu \mathrm{m}$ without). The rays of the triradiate ridge are prominent, $c .50 \mu \mathrm{m}$ wide and $30-40 \mu \mathrm{m}$ high and extend to approximately $\frac{2}{3}$ of the radius of the spore. The exoexine is $c .20 \mu \mathrm{m}$ thick and underlain by a much thinner (c. $1 \mu \mathrm{m})$ intexine.

Other species. The following species are transferred to Cabochonicus on the basis of the criteria set out in the diagnosis:

1. Cabochonicus imitatus (Dijkstra) comb. nov. Basionym: Triletes imitatus Dijkstra 1961, p. 12, pl. 1, figs. 1a, 1b, 2.

2. Cabochonicus pseudosquamosus (Marcinkiewicz) comb. nov.

Basionym: Verrutriletes pseudosquamosus Marcinkiewicz, 1962, pp. 491-2, pl. 9, figs. 1, 2.

3. Cabochonicus guttatus (Marcinkiewicz) comb. nov. Basionym: Verrutriletes guttatus Marcinkiewicz, 1971 , p. 56, pl. 5, figs. 4-8; pl. 6, figs. 1-6.

4. Cabochonicus? gamerroi (Baldoni \& Taylor) comb. nov.

Basionym: Triletes gamerroi Baldoni \& Taylor, 1985, pp. 152 and 156; pl. 1, figs. 1-6; pl. 2, figs. 1-4.

The three whole specimens of Triletes gamerroi that are illustrated in Baldoni \& Taylor (1985, pl. 1, figs. 1-3), one of which is the holotype, are sculptured with

\section{Explanation of Plate 4}

All ultrathin sections of specimen 4; Cabochonicus carbunculus from the English Wealden (Lower Cretaceous, Ashdown Beds Formation, sample DJB 218).

Figs. 1, 3-6. Structure of exoexine is similar to that of specimen 2, Pl. 3, figs. 4-7. Surface excrescences are of variable form $($ all $\times 2500)$.

Fig. 2. Tangential section through exoexine $(\times 5000)$. 

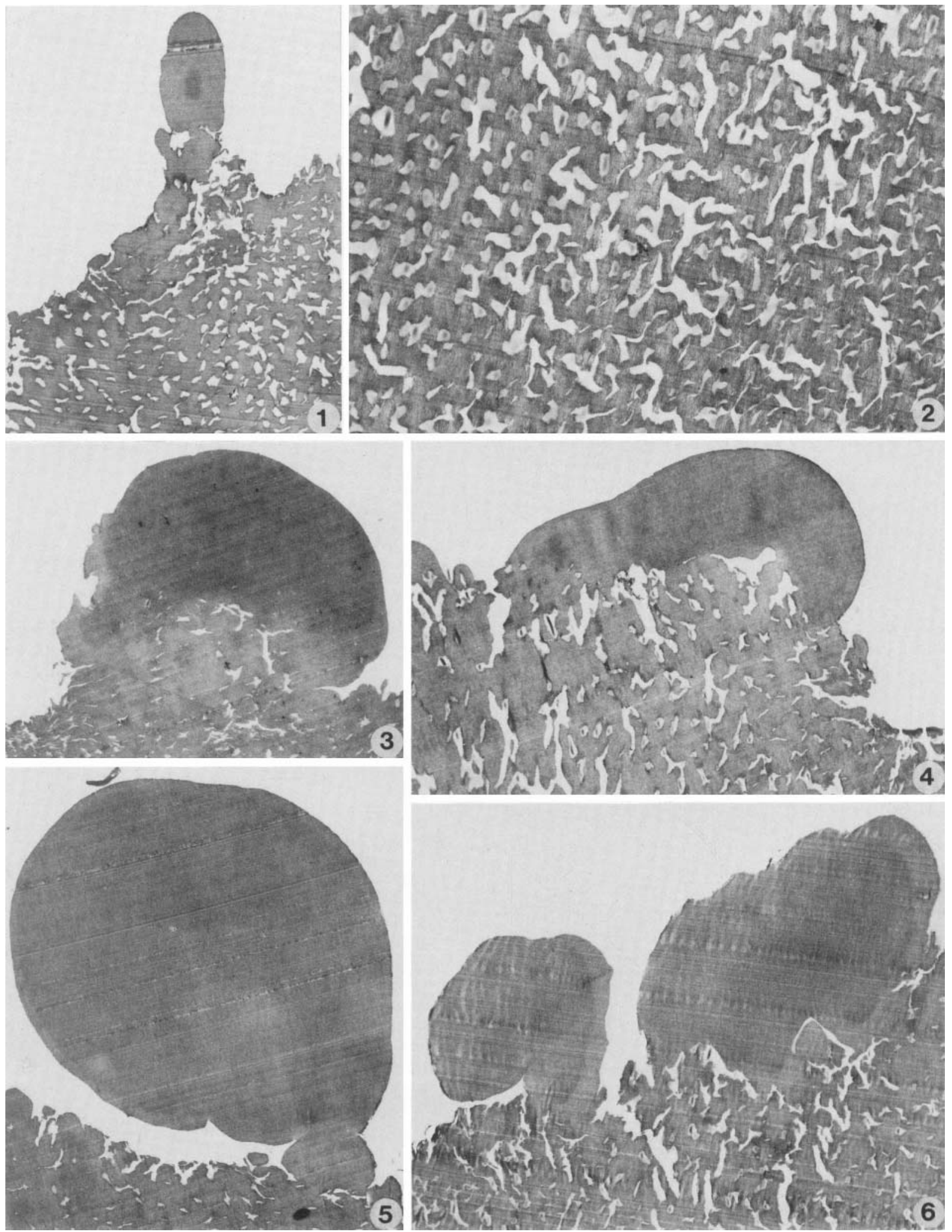
scattered gemmae. These elements are not mentioned in either the diagnosis or the description of the species because they were considered to be "foreign bodies". It is tentatively suggested here that reference to Cabochonicus rather than Triletes might be appropriate for at least part of the assemblage on which this taxon is based.

Stratigraphic range of genus. Published records suggest that this is Late Rhaetian to Santonian.

Remarks. Hueber (1982, p. 5) noted that his spores "seem encrusted over most of their surfaces with minute, lustrous, ruby cabochons". Reference of these elements to polished but uncut precious stones seems even more appropriate than other previously employed qualifiers such as glass beads and resinous spherules, hence its selection as the basis of the new generic name. Truly verrucate spores should continue to be referred to Verrutriletes as originally described by Potonié (1956) and emended by Binda \& Srivastava (1968). Trileites is maintained for essentially smooth-walled forms. It is accepted that some specimens referable to the latter genus may be in fact be degraded examples of Cabochonicus which have lost their excrescences but this can be difficult to prove. Corrosion often removes characters that are critical for spore identification. It is not a problem unique to these genera.

Cabochonicus cannot be satisfactorily classified using Potonié's (1956 et. seq.) scheme since it is neither a smooth nor a verrucate spore and hence is not referable to either of the Infraturmas Laevigati or Apiculati. No attempt is made to place it elsewhere or to create a new category because this is not seen to serve any useful purpose. The value of purely morphological classification is becoming increasingly unclear as research continues on dispersed spores and their relationships with the plants that produced them.

\section{AFFINITY}

It is assumed that Cabochonicus is a lycopod megaspore. In common with others of the group, the sporopollenin wall layers comprise a thick, spongy exoexine and a much thinner intexine. Of the two modern heterosporous orders, the Selaginellales and the Isoetales, the external form and internal structure of Cabochonicus bear more resemblance to the products of a few species of Selaginella (cf. Minaki, 1985) than to Isoetes but no direct comparison is possible. The exines of spores of extant Isoetes and of fossil forms that have been attributed to the Isoetales (e.g. Hall, 1963; Pettitt, 1966; Collinson et al., 1985; Kovach \& Dilcher, 1985) are more open in texture and no laminated intexine is detectable. Origins within now extinct families such as the Pleuromeiaceae are possible but positive evidence is wanting.

The selaginellids have a long history that extends from the Carboniferous and living members, of which there are about 700 , show considerable ecological adaptation in habitats. They are, however, usually terrestrial. The tendency for Cabochonicus to occur only sporadically and in low numbers in sediments suggests that the plants which produced them also inhabited dry land. This is in sharp contrast to species of such genera as Minerisporites Potonié 1956 and Paxillitriletes Hall \& Nicolson, 1973 which may be very abundant and suggest local derivation from aquatic or semi-aquatic members of the Isoetaceae (Batten, 1975, 1982; Collinson et al., 1985; Kovach \& Dilcher, 1985).

\section{CONCLUSION}

The natural affinity of the heterosporous plant that produced Cabochonicus carbunculus and other species of the genus remains uncertain but a subgroup of the Selaginellales is a possibility. The sculpture is, however, clearly neither verrucate nor the result of fungal attack but rather consists of exinal excrescences that are often gemmate in form.

\section{ACKNOWLEDGEMENTS}

Access to S. J. Dijkstra's megaspore collection in the Geologisch Bureau of the Rijks Geologische Dienst, Heerlen, The Netherlands and the interest of Dr. $\mathrm{H}$. van de Laar are greatly appreciated. We are also grateful for being able to make use of scanning electron microscopes at the University of East Anglia and the British Museum (Natural History).

\section{Manuscript received June 1986}

Revised manuscript accepted August 1986

\section{REFERENCES}

Baldoni, A. M. \& Taylor, T. N. 1985. Megasporas Cretacicas de la Formacion Springhill en el subsuelo de Argentina y Chile austral. Ameghiniana, 21, 151-167.

Banerji, J., Jana, B. N. \& Maheshwari, H. K. 1984. The fossil floras of Kachchh. II. Mesozoic megaspores. Palaeobotanist, 33, 190-227.

Batten, D. J. 1969. Some British Wealden megaspores and their facies distribution. Palaeontology, 12, 333-350.

Batten, D. J. 1975. Wealden palaeoecology from the distribution of plant fossils. Proc. Geol. Ass., 85 (for 1974), 433-458.

Batten, D. J. 1982. Palynofacies and salinity in the Purbeck and Wealden of southern England. In Banner, F. T. \& Lord, A. R. (Eds.), Aspects of Micropalaeontology, 278-308. George Allen \& Unwin, London.

Batten, D. J. \& Li Wenben. In press. Aspects of palynomorph distribution, floral provinces and climate during the Cretaceous. Geol $\mathrm{Jb}$.

Batten, D. J., Creber, G. T. \& Zhou Zhiyan. 1984. Fossil plants and other organic debris in Cretaceous sediments from Deep Sea Drilling Project Leg 80: their palaeoenvironmental significance and source potential. Init. Repts. Deep Sea Drilling Project, 80, 629-641. 
Bergad, R. D. 1978. Ultrastructural studies of selected North American Cretaceous megaspores of Minerisporites, Erlansonisporites, Horstisporites and Ricinospora, n. gen. Palynology, 2, 39-51.

Binda, P. L. \& Srivastava, S. K. 1968. Silicified megaspores from Upper Cretaceous beds of southern Alberta, Canada. Micropaleontology, 14, 105-113.

Collinson, M. E., Batten, D. J., Scott, A. C. \& Ayonghe, S. N. 1985. Palaeozoic, Mesozoic and contemporaneous megaspores from the Tertiary of southern England: indicators of sedimentary provenance and ancient vegetation. $J$. geol. Soc. London, 142, 375-395.

Dijkstra, S. J. 1949. Megaspores and some other fossils from the Aachenian (Senonian) in south Limburg, Netherlands. Meded. geol. Sticht., N.S., 3, 19-32.

Dijkstra, S. J. 1951. Wealden megaspores and their stratigraphical value. Meded. geol. Sticht., N.S., 5, 7-22.

Dijkstra, S. J. 1961. On megaspores, Charophyta fruits and some other small fossils from the Cretaceous. Palaeobotanist, 8 (for 1959), 8-18.

Hall, J. W. 1963. Megaspores and other fossils in the Dakota Formation (Cenomanian) of Iowa (U.S.A.) Pollen Spores, $5,425-443$

Hall, J. W. \& Nicolson, D. H. 1973. Paxillitriletes, a new name for fossil megaspores hitherto invalidly named Thomsonia. Taxon, 22, 319-320.

Harris, T. M. 1961. The Yorkshire Jurassic Flora I. Thallophyta - Pteridophyta. ix +212 pp. Br. Mus. nat. Hist., London.

Huckriede, R. 1982. Die unterkretazische Karsthöhlen Füllung von Nehden im Sauerland. 1. Geologische, paläozoologische und paläobotanische Befunde und Datierung. Geologica et Palaeontologica, 16, 183-242.

Hueber, F. M. 1982. Megaspores and a palynomorph from the Lower Potomac Group in Virginia. Smithson. Contr. Paleobiol., 49, iii +69 pp.

Kampmann, H. 1983. Mikrofossilien, Hölzer, Zapfen und Pflanzenreste aus der unterkretazische Sauriergrube bei Brilon - Nehden. Geol. Paläont. Westf., 1, 146 pp.

Kempf, E. K. 1970. Elektronenmikroskopie der Sporodermis von Megasporen der Gattung Selaginella (Pteridophyta). Rev. Palaeobot. Palynol., 10, 99-116.

Kempf, E. K. 1971. Electron microscopy of Mesozoic megaspores from Denmark. Grana, 11, 151-163.

Kempf, E. K. 1973. Transmission electron microscopy of fossil spores. Palaeontology, 16, 787-797.

Knobloch, E. 1984a. Megasporen aus der Kreide von Mitteleuropa. Sb. geol. Vèd, Paleont., 26, 157-195.

Knobloch, E. 1984b. Megasporen aus der Kreide (Oberconiak-Santon) der Bohrung Volfartice (Nordböhmen). Cas. Miner. Geol., 29, 155-165.

Kovach, W. L. \& Dilcher, D. L. 1985. Morphology, ultrastructure, and paleoecology of Paxillitriletes vittatus sp. nov. from the mid-Cretaceous (Cenomanian) of Kansas. Palynology, 9, 85-94.

Marcinkiewicz, T. 1962. Rhaetian and Liassic megaspores from the Mechowo Borehole near Kamień Pomorski and their stratigraphical value. Pr. Inst. geol., 30, $469-493$ (in Polish, English summary)

Marcinkiewicz, T. 1971. The stratigraphy of the Rhaetian and Lias of Poland based on megaspore investigations. Pr. Inst. geol., 65, $58 \mathrm{pp}$ (in Polish. English summary)

Marcinkiewicz, T. 1979. Fungi-like forms on Jurassic megaspores. Acta palaeobotanica, Cracov, 20, 123-128.
Marcinkiewicz, T. 1980. Jurassic megaspores from Grojec near Kraków. Acta palaeobotanica, Cracov, 21, 37-60.

Minaki, M. 1985. Macrospore morphology and taxonomy of Selaginella (Selaginellaceae). Pollen Spores, 26 (for 1984), 421-479.

Peltzer, G. \& Riegel, W. 1982. Megasporen aus der Bückeberg - Formation 1 (Wealden) des Osterwaldes eine Vorläufige mitteilung. Cour. Forsch. - Inst. Senckenberg, 56, 23-32.

Pettitt, J. M. 1966. Exine structures in some fossil and recent spores and pollen as revealed by light and electron microscopy. Bull. Br. Mus. nat. Hist. (Geol.), 13, 221-257.

Potonié R. 1956. Synopsis der Gattungen der Sporae dispersae. I. Sporites. Beih. Geol. Jb., 23, 103 pp.

Tryon, A. F. \& Lugardon, B. 1978. Wall structure and mineral content in Selaginella spores. Pollen Spores, 20, 315-340.

van der Hammen, T. 1954. El desarrollo de la Flora Colombiana en los Periodos Geologicos I: Maestrichtiano hasta Terciario mas inferior. Una investigación palinológica de la formación de Guaduas y equivalentes. Bol. Geol., 2, 49-106.

Waksmundzka, M. 1982. Lower Cretaceous megaspores from northern Poland. Acta. palaeont. pol.. 27, 147-156.

Waksmundzka, M. 1985. Nature of ornamentation in megaspores of the genus Verrutriletes. Acta palaeont. pol., $\mathbf{3 0}$, 93-98. 